\title{
The Correlates of Two Types of Leadership Motivation
}

\author{
Krzysztof Nowak* \& Raphael Mahari**
}

\begin{abstract}
Summary
The paper deals with the sense of satisfaction in people with traits related to effective leadership, considering three domains: personal, achievement, and self-worth. A segmentation analysis performed on 580 current or future employees, who combine their work with studying management at the University of Warsaw, revealed two groups that had traits related to effective leadership. The subjective feeling of satisfaction across three domains: personal relationships, work-related satisfaction, and self-worth, was compared between both groups with leadership trait profiles and peers with non-leadership trait profiles. Both groups with leadership trait profiles had a higher feeling of satisfaction in work/school relative to their peers. The leadership trait profile group with a high need for power, medium need for achievements and low need for affiliation had higher self-acceptance than peers, while the leadership group with a high need for power, need for achievement and need for affiliation had higher satisfaction with relationships than their peers. Participants in both leadership trait profile groups were divided based on their temperament and preferred working style. Although highly reactive individuals in both groups felt less satisfaction with work/school, this effect was completely canceled out for individuals with a working style matched to a leadership position in the group with a high need for affiliation and achievement. Implications of these findings for organizational practice are discussed.
\end{abstract}

Keywords: leadership motive profile theory, temperament, activity-style, sense of satisfaction

JEL: M12, O15, J24

\section{INTRODUCTION}

Leadership is key to organizational success. Groups of people working together have achieved the most extraordinary human accomplishments. Through history, the members of these groups became more specialized for specific tasks and group roles became more defined. In modern companies, diversification and specialization improve quality and efficiency, but this also means that the company needs to hire more people. The problem with growing companies is that communication, organization, and decision-making became more difficult. Therefore, companies need leaders to ensure efficient operation irrespective of the size.

Who is a leader, and what is his or her impact on an organization? A leader is a single individual with enormous influence on a group of people (De Jong \& Den Hartog 2007). Evidence strongly suggests that leaders have major impact on job performance. One study examined the effect leaders have on vigor. The study found that a good leader can impact vigor which in turn affects job performance (Carmeli, Ben-Hador, Waldman, \& Rupp, 2009). It has also been shown that poor leadership can decrease both job satisfaction and the company's reputation among employees (Schyns \& Schilling, 2013). Many modern company types, such as tech companies, require highly trained and specialized personnel. Employees are essential for companies but, in some cases, finding them is also difficult. Therefore, if their job satisfaction in the company they work for is low, many talented employees will leave, which can result in loss of profits (Yukl, 2008). Studies found evidence that 23.8 billion U.S. dollars are lost by companies due to poor leadership each year in the U.S.A. alone (Schyns \& Schilling, 2013).

A leader affects job performance and innovative behavior. Many modern companies can only remain competitive and profitable by innovating regularly. A company's employees contribute much

\footnotetext{
* Faculty of Management, University of Warsaw, Poland, https://orcid.org/0000-0001-9615-1222

** Tulane University, New Orleans, Louisiana, USA
} 
to its innovation. The importance of $R \& D$ teams and general innovative behavior from employees is already apparent from the massive amounts spent on innovative behavior. Still, recent studies suggest that an essential component of an innovative environment is the leader (De Jong \& Den Hartog, 2007).

Leaders affect the general effectiveness of companies. While it is not always a company's main priority to be efficient, leaders are both essential to identifying the company's priorities and implementing them. Therefore, if a company does not have appropriate leadership, then the goal and its implementation might have adverse effects on profit (Yukl, 2008).

These are just a few examples that show an ever-growing body of evidence suggesting that leaders are essential to establishing, maintaining and regulating companies. Leaders can mean the difference between a profitable company and a company going bankrupt. However, there are many types of leaders and leadership styles. Depending on various variables, some leaders are better suited to their task than are others. A company must not only find a good leader but a good leader suited to the company's (or department) specific environment.

\section{THEORETICAL BACKGROUND}

\section{Leadership motive profile theory}

Since the 1960's, McClelland's motivation theory (McClelland, 1961) has been used in assessing what drives people in the workplace. This theory is based on the premise that three basic needs are key:

- need for power

- need for affiliation

- need for achievement.

Need for power is realized when a person has control over the decisions and processes by other people or groups (MClelland, 1970). Need for affiliation refers to the subjective feeling of contact and getting along well with other people (Deci \& Ryan, 2000). Need for achievement is realized through feeling competent at the tasks one performs.

The structure of these needs plays off each of them and is thought to regulate a person's actions. For example, an underpaid middle manager with a high need for affiliation may prefer to not ask for a rise from his or her employer in order to avoid conflict, while a fellow manager with a high need for power and a low need for affiliation may use conflict to strengthen his or her position within the company. Thus, various profiles of these needs have been associated with successful career outcomes.

One such profile refers to leaders. Effective leadership has been associated with a particular structure of needs: high need for power, medium need for achievement and low need for affiliation. This combination of needs has been termed McClelland's leadership motive profile (McClelland \& Burnham, 1976).

Recently, it has been found that another leadership motive profile is associated with a favorable outcome in modern organizations: relationship-focused high achievers (Steinmann, et al. 2015). This profile has a high need for power, achievement and affiliation. Managers with this profile have been found to earn more than their peers and achieve team goals more frequently. Thus, they are more successful which is reflected in greater satisfaction.

\section{Leadership cognitive resource theory}

Different attributes make leaders more or less suitable for specific tasks and environments. Numerous research papers have examined specific leadership attributes and their effect on the company. A major theory dealing with this topic was Fiedler's contingency model of leadership (Fiedler, 
1967) and the modified version: cognitive resource theory (Fiedler, 1986). The latter proposes to explain the link between cognitive resources and leadership performance. In stable and low-stress situations, higher cognitive resources (intelligence being among them) are proposed to increase leadership performance. In highly chaotic and stressful environments, highly intelligent leaders are predicted to perform worse than less intelligent leaders. This prediction is exceptionally accurate for leaders with considerable experience to guide them in decision-making.

Cognitive resource theory aims to explain why, while more intelligent leaders have many benefits, more effective planning, decision-making and employee training being among them, the relationship between leadership intelligence and leadership is weak at best (Neider \& Schriesheim, 1988). This is especially surprising since it has been empirically demonstrated that employees who are provided training enchancing the cognitive resources avalable to them can come up with solutions of considerably higher quality and originality (Mumford, Todd, Higgs \& McIntosh, 2017). For example, one study found that the correlation between leadership intelligence and leadership effectiveness in mid- and higher-level managers had a correlation of just 0.22 and decreased when job stress was high (Judge et al. 2004).

\section{Temperament and working style misfit in leaders}

A leader's individual characteristics and preferred working style may fit to various degrees the demands of his or her role in an organization. As a leadership position is often prestigious, and often pays well a leadership position may be sought after by individuals who's temperament (eg. a person reacting very strongly to stressful situations) or working style (a person not liking to change the way of approaching a problem), does not fit to a highly stressful and chaotic environment. A mismatch between temperamental characteristics, associated with a low level of resources and a working style and environment requiring a lot of cognitive resources has been described as a lasting "sore point" (Eliasz, 2006). Such a mismatch can be associated with psychological costs to the leader, and reduced leader effectiveness posing costs for the organization as a whole.

One study that has shown how personality characteristics can be associated with increased costs while performing tasks with different requirements of working styles comes from Szymura and Nęcka (1998). In the study, introverts and extraverts were given two tasks and had to perform then in one of two conditions. In the first condition the participants could focus on one task at a time, while in the second condition they had to complete the tasks simultaneously. While introverts performed better in the condition where they could focus on one task, extraverts performed better when multitasking. This was consistent with the hypothesis that extraverts have a higher need for stimulation and resources needed to complete tasks under stressful situations then do introverts.

Studies also show that people can modify their working styles based on work demands (Wieczorkowska, 1998; Wieczorkowska et al., 2009). In response to instructions requiring various levels of precision when performing a task, people are able to temporarily change their working style. Hover, temperamental characteristics are much more persistent, to changing work demands. In the case of a leadership position, that demands many decisions in a chaotic environment, this can lead to the aforementioned mismatch.

Studies on job requirements - employee personality misfit have found that (Jeśka, 2016, Wieczorkowska, Król, Wierzbiński, 2015):

- when performing tasks that require following a strict procedure, employees that have a more methodical working style incur smaller psychological costs then employees that have a less methodical working style; 
- in workplaces where there are more formalized procedures, less reactive employees earn more;

- less reactive employees deal with multitasking and chaotic work environments better then more reactive employees.

Since working environments in leadership positions rarely have clear procedures and are constantly changing and highly demanding, a preference for non-methodical work can fit such an environment better and thus protect some highly reactive leaders from too high levels of stress.

\section{Research question and hypotheses}

This paper deals with two research questions concerning leadership and satisfaction:

1. How are leadership traits related to sense of satisfaction?

2. Can a leader's working style that is well-suited to his or her temperament and environment influence his or her sense of satisfaction?

The hypotheses related to these were as follows:

H1 People with high leadership motivation feel a higher level of satisfaction than their peers.

$H 2$ Various profiles of leadership traits are related to sense of satisfaction across different domains.

H3 Leaders with a working style suited to their temperament and environment feel greater satisfaction than leaders with a working style unsuited to their temperament.

\section{METHOD}

\section{Participants}

Five hundred eighty (580) faculty students and participants of the MBA program at the faculty of Management at the University of Warsaw took part in the study. $394(68 \%)$ of them were women and $186(32 \%)$ men. Their mean age was $18-56$, with a mean age of 23.08 years $(\mathrm{SD}=4.52)$. All were sent a link to an online questionnaire consisting of an updated version of the Survey of Activity styles as well as supplementary questions.

\section{Measures}

Survey of Activity styles. A revised version of the Survey of Activity Styles (SAS) has been used. This tool has been validated and used multiple times in research in Poland (e.g., WieczorkowskaNejtardt, 1998; Wieczorkowska \& Burnstein, 1999; Turska, 2014). It consists of a variety of statements about two hypothetical people. The participant is asked to indicate whether he is more like person A or B on a 5-point scale:

- typically, like person A,

- more often like person A,

- more often like person B,

- typically, like person B,

- it is hard to say.

"Typically, like person A" corresponds to a value of 1 and "typically, like person B" to value 5, and "it is hard to say" corresponds to the median value: 3. Below are lists of questions comprising the scales used in the study. Measures of reliability as well as cross tables, with a frequency of each response, may be found in the Appendix. 
Preference for a methodical working style:

- Person A commences a task only once he or she has thought of a method to do it. Person B starts a task even before he or she knows exactly how to do it and hopes to figure it out on the fly.

- Person A starts writing an essay not knowing what he or she will write. Person B first thinks of the essay's structure and only then begins writing it.

- Person A often starts tasks thinking that things will work out. Person B feels worried if he or she does not know how to do something.

- When person $\mathrm{A}$ is preparing to start a new task, he or she always prepares the required materials and tools beforehand. Person B finds the required tools and materials while doing the task so as not to delay commencing the task.

- Person A always completes tasks in a set order while person B does the tasks in a different order because it is easier or more interesting for him or her.

Reactivity:

- When person A sleeps less than usual, he or she usually feels worn out and tired. Person B can work intensely after a sleepless night.

- When upset, person A has difficulty focusing on a book or a newspaper and often reads the same sentence several times. If necessary, person B is able to focus on this situation.

- Person A works very well at the last minute. Time pressure disorganizes the behavior of person B.

- Person A belongs to those resistant to stress. Person B always sleeps worse BEFORE an important event (an exam, a long journey).

- Person A does not like deciding under time pressure, for person B pressure makes it easier to make decisions

Need for power:

- When working in a team, it is easier for person A when somebody else is responsible for the task. Person B prefers to be the one responsible for the task.

- Person A prefers to let someone else be responsible for planning and decisions, Person B prefers to plan and decide for others.

- Person A likes when someone else decides for him or her. Person B feels irritated when someone else decides for him or her.

- Person A usually plays the role of group leader. Person B shuns the responsibility associated with being a leader.

- When taking part in group activities, person A feels good in a leadership role. Person B does not feel comfortable deciding how his or her team performs its tasks.

Need for affiliation:

- People say that person A is an individualist that always worries about his or her own interest. Person B tries to take other peoples' best interest into account when doing things.

- Person A does not like it when others come to him or her with their problems. Friends of person B always know they can count on him or her when they have issues.

- Person A likes tasks in which he or she can compete with others. Person B prefers situations that require cooperation.

- Before person A makes a decision, he or she tries to imagine what others think. Person B does not care about the point of view of other people.

- Person A does not understand why he or she has to think of other people's feelings. Person B thinks of other's point of view before he or she decides how to act. 
Need for achievement:

- Person A often works until collapse, or tries to do more than he or she can. Person B avoids overworking him or herself.

- Person $\mathrm{A}$ is more demanding of him or herself because he or she tries to live the most efficient life possible. B does not want to overwork himself or herself.

- Person A could probably achieve more but does not see a reason to work more than necessary. Person B works more than other people.

- Person B does not want to work more than he or she is being paid for. Person A has a tendency to fully engage in work that he or she is working on without regard to the amount of money he or she is being paid.

- Person A feels bad when he or she does not have a lot to do at work. Person B prefers work that does not require his or her full engagement.

Feeling of satisfaction:

The feeling of satisfaction was measured on a 7-point Likert-type scale indicating whether a person feels that he or she satisfied with a given domain ( 1 - very bad, 7 - very good). The feeling of satisfaction with work/school was measured using the question: "Overall, compared to my peers, I rate my achievements at work/school as:" The feeling of satisfaction with relationships was measured with the question: "Overall I rate my relationships with other people as:" The sense of satisfaction associated with one's self-worth was measured with the question: "Overall I rate myself as:".

\section{Analytic strategy}

A model-based cluster analysis was used to segment the participants based on the need for power, need for achievement and need for affiliation and to distinguish leadership trait profiles. This was done using the MCLUST package (Scrucca et al., 2016) that uses a Bayesian Information Criterion to determine the best clustering model and the number of clusters. This approach has the advantage of comparing many types of clustering methods in one framework, and removing the arbitrary choice of choosing the number of clusters. The variables were standardized before clustering to ensure the best solution. Next, the subjective sense of satisfaction (at work/school, self-work, and in relationships) was compared between the various groups using a linear model with age and gender as covariates. Lastly, participants were additionally split into groups of high and low reactivity and preference for methodical working style based on the median. In both leadership groups with a leadership profile, a linear model with interaction was used to determine the effect of reactivity and preference for methodical working style on the subjective feeling of satisfaction at work/school.

\section{RESULTS}

\section{Leadership trait profiles}

Participants were segmented into four groups (see Table 1). Two groups had a high need for power and were congruent with a) McClelland's classic leadership motive profile (LMP) characterized by a high need for power, medium need for achievement and low need for affiliation; and b) a leader motive profile with a high need for power, achievement, and motivation. We labeled them as McClelland's classic LMP and relationship-focused high achiever LMP, respectively. The two nonleadership motive profiles both had a low need for power, but one had medium need for achievement and high need for affiliation, while the other had a low need for both achievement and power. Both groups were combined for further analyses as the paper's focus is on the differences between leadership and non-leadership profiles. The descriptive statistics in both leadership profile groups 
and non-leadership profile group can be seen in Table 1. All groups had a very similar age profile. However, there were slightly more females ( $72 \%$ vs. $68 \%$ for the rest of the participants) in the relationship-focused high achievers' group than in either one of the other groups.

Table 1. Descriptive statistics within the clusters corresponding to McClelland's classic LMP, relationship-focused high achievers LMP and non LMP participants

\begin{tabular}{lccc}
\hline & McClelland's LMP & $\begin{array}{c}\text { Relationship-focused } \\
\text { high achiever LMP }\end{array}$ & Non-LMP \\
\hline Need for power & $4.42(0.40)$ & $4.91(0.33)$ & $3.13(0.88)$ \\
Need for achievement & $3.90(0.43)$ & $4.80(0.18)$ & $3.23(0.89)$ \\
Need for affiliation & $3.15(0.69)$ & $4.13(0.69)$ & $3.88(0.71)$ \\
Gender - female & $68 \%$ & $72 \%$ & $68 \%$ \\
Age & $23.14(4.84)$ & $23.26(3.71)$ & $23.03(4.52)$ \\
\hline
\end{tabular}

Notes: The tables show the mean (standard deviation) of the variables in the three groups found in the cluster analysis.

\section{Leadership motive profile and sense of satisfaction}

Sense of satisfaction at work/school was higher for both leadership motive profiles relative to their peers (Table 2). The McClelland's classic LMP was associated with a greater sense of satisfaction related to self-worth compared to peers, while the relationship-oriented high achievers LMP was related to greater sense of satisfaction related to personal relationships relative to peers. The results can be seen in Figure 2 and the results of the model comparing these groups appear in Table 2. Additionally, women had a lower sense of satisfaction related to achievements at work/school and a lower sense of satisfaction related to self-worth. Age was not significantly related to sense of satisfaction in any case.

Table 2. The effect of leadership motive profiles on the feeling of satisfaction across three domains: achievements at work/school, personal relationships, and self-worth

\begin{tabular}{|c|c|c|c|c|c|c|c|c|c|}
\hline & \multicolumn{3}{|c|}{ Achievements at work/school } & \multicolumn{3}{|c|}{ Personal relationships } & \multicolumn{3}{|c|}{ Self-worth } \\
\hline & beta & $t$ & $p$ & beta & $t$ & $p$ & beta & $t$ & $p$ \\
\hline McClelland's LMP & 0.24 & 5.92 & $<0.001$ & 0.02 & 0.44 & 0.66 & 0.15 & 3.71 & $<0.001$ \\
\hline $\begin{array}{l}\text { Relationship-oriented } \\
\text { high achiever LMP }\end{array}$ & 0.2 & 4.83 & $<0.001$ & 0.12 & 2.77 & 0.006 & 0.08 & 2 & $<0.05$ \\
\hline Age & 0.02 & 0.5 & $<0.62$ & 0.06 & 1.38 & 0.17 & 0.07 & 1.75 & $<0.08$ \\
\hline Gender & -0.09 & 2.26 & $<0.02$ & 0.008 & 0.2 & 0.84 & -0.12 & -2.77 & $<0.005$ \\
\hline$F$ & & 13.95 & & & 2.44 & & & 7.34 & \\
\hline$p$ & & $<0.001$ & & & 0.05 & & & $<0.001$ & \\
\hline$R^{\wedge} 2$ & & 0.09 & & & 0.02 & & & 0.05 & \\
\hline
\end{tabular}

Note: beta refers to the standardized regression coefficients.

\section{The consequences of temperament and working-style mismatch in leaders}

Among participants with McClelland's classic LMP, higher reactivity was associated with significantly lower sense of satisfaction related to work/school level achievements irrespective of the preferred working-style. See Figure 3 A for the graphical comparison of the low and high 
reactivity group and the low and high preference for methodical working-style groups. See Table 3 for the model coefficients.

Figure 1. The interaction of reactivity and a methodical working-style on the feeling of satisfaction through achievements at work/school for the relationship-focused high achievers LMP.

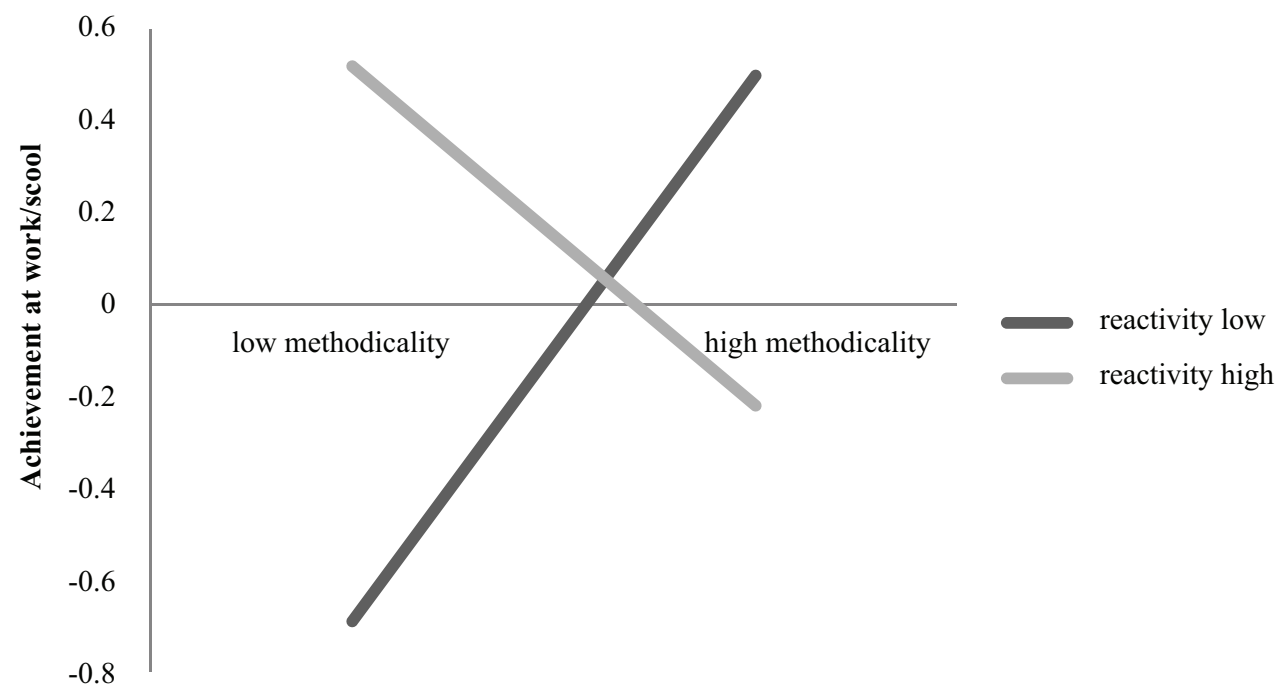

Among participants with a relationship-oriented high achiever LMP with a non-methodical working-style, reactivity was not significantly associated with the feeling of satisfaction with achievements in work/school. For participants with highly methodical working-style the pattern was the same as in the McClelland's classic LMP: high reactivity was associated with a lower feeling of satisfaction in work/school achievements. See Figure 3 B for graphical comparison of the low and high reactivity group and low and high preference for methodical working-style groups. See also Table 3 for the model coefficients. Neither age nor gender was significantly associated with the sense of satisfaction with achievements in work/school in either group.

Table 3. The effect of reactivity, methodical working-style and their interaction on sense of satisfaction in work/study related achievements

\begin{tabular}{lcccccccc}
\hline & \multicolumn{3}{c}{ McClelland's LMP } & & \multicolumn{3}{c}{ Relationship-oriented high achievers LMP } \\
\cline { 2 - 3 } & beta & $t$ & $p$ & & beta & $t$ & $p$ \\
\hline Reactivity & $-0.46^{*}$ & -3.36 & 0.001 & & 0.15 & 0.72 & 0.47 \\
Methodical working-style & 0.05 & 0.49 & 0.62 & & 0.14 & 0.94 & 0.35 \\
Reactivity x methodical & & & & & & & \\
working-style & 0.15 & 0.96 & 0.32 & & $-0.51^{*}$ & -2.14 & 0.04 \\
Age & -0.03 & -0.38 & 0.71 & & 0.06 & 0.41 & 0.68 \\
Gender & 0.03 & -2.26 & 0.02 & & -0.02 & -0.17 & 0.86 \\
\hline$F$ & & 4.00 & & & & 1.6 & \\
$p$ & & 0.002 & & & & 0.18 & \\
$R^{\wedge} 2$ & & 0.14 & & & & 0.13 & \\
\hline
\end{tabular}

Note: beta refers to the standardized regression coefficients and * to significance below the $\mathrm{p}<0.05$ level. 


\section{CONCLUSIONS}

Based on the need for power, need for affiliation, and need for achievement we have found two leadership motive profiles. One of these was associated with McClelland's classic leader motive profile that has a high need for power, medium need for achievement, and low need for affiliation. This leadership motive profile was shown in various studies to be related to successful leadership. The other leadership motive profile found was a relationship-focused high achievers leadership motive profile, characterized by a simultaneous high need for power, affiliation, and need for achievement. This motive profile was recently found predictive of effective leadership in modern organizations.

Both leadership motive profiles were related to a higher sense of satisfaction in work or study-related achievements relative to peers as well as satisfaction related to self-worth. However, only the relationship-focused high achievers' group had a higher sense of satisfaction in personal relationships compared to peers. Additionally, we found that relationship-focused high achievers that had a temperament predisposing them to feel lower satisfaction related to achievements at work or school, could compensate by adopting a working style suited to a leadership-like role, which was not true for the McClelland's classic leadership motive profile group. In this group, adopting a working style better suited to leadership and work environment did not diminish the effect of temperament on the feeling of satisfaction.

These findings show that sense of satisfaction across personal, work, and relationship domains, is higher for leader motive profiles relative to peers. Additionally, relationship-focused high achievers seem to have more opportunities to enhance their sense of satisfaction compared to McClelland's classic leadership motive profile. First of all, by focusing on relationships, they can achieve a greater sense of satisfaction when successful in a domain not necessarily directly related to work outcome. Second of all, they can increase their sense of satisfaction in work achievements by modifying their working style to fit their temperament. Further work is needed to examine how the subjective sense of satisfaction across the dimensions studied here is related to leadership effectiveness in the context of leadership motive profile theory.

\section{Literature}

Carmeli, A., Ben-Hador, B., Waldman, D. A., \& Rupp, D. E. (2009). How leaders cultivate social capital and nurture employee vigor: Implications for job performance. Journal of Applied Psychology, 94(6), 1553.

Deci, E. L., \& Ryan, R. M. (2000). The" what" and" why" of goal pursuits: Human needs and the self-determination of behavior. Psychological Inquiry, 11(4), 227-268.

De Jong, J. P., \& Den Hartog, D. N. (2007). How leaders influence employees' innovative behaviour. European Journal of Innovation Management, 10(1), 41-64.

Eliasz, A. (2006). Internal incongruence among personality mechanisms as a constant 'sore point'. European Health Psychologist, 8(2), 5-7.

Fiedler, F. E. (1986). The Contribution of Cognitive Resources and Leader Behavior to Organizational Performance 1. Journal of Applied Social Psychology, 16(6), 532-548.

Jeśka, M. (2016). The consequences of the fit between employee characteristic and tasks differing in the degree of process standardization. (Doctoral dissertation, University of Warsaw.).

Judge, T. A., Colbert, A. E., \& Ilies, R. (2004). Intelligence and leadership: a quantitative review and test of theoretical propositions. Journal of Applied Psychology, 89(3), 542.

McClelland, D. (1961). The achieving society. New York: Van Nostrand Reinhold.

McClelland, D. (1970). The two faces of power. Journal of International Affairs, 24(1), 29-47.

McClelland, D. C., \& Burnham, D. H. (1976). Power is the Great Motivator. Harvard business review, 54(2), 100-110.

Mumford, M. D., Todd, E. M., Higgs, C., \& McIntosh, T. (2017). Cognitive skills and leadership performance: The nine critical skills. The Leadership Quarterly, 28(1), 24-39. 
Scrucca, L., Fop, M., Murphy, T. B., \& Raftery, A. E. (2016). Mclust 5: clustering, classification and density estimation using Gaussian finite mixture models. The R Journal, 8(1), 289.

Steinmann, B., Dörr, S. L., Schultheiss, O. C., \& Maier, G. W. (2015). Implicit motives and leadership performance revisited: What constitutes the leadership motive pattern? Motivation and Emotion, 39(2), 167-174.

Szymura, B., \& Nęcka, E. (1998). Visual selective attention and personality: An experimental verification of three models of extra version. Personality and Individual Differences, 24(5), 713-729.

Schyns, B., \& Schilling, J. (2013). How bad are the effects of bad leaders? A meta-analysis of destructive leadership and its outcomes. The Leadership Quarterly, 24(1), 138-158.

Turska, E., Uniwersytet Śląski (Katowice), \& Wydawnictwo. (2014). Kapitał kariery ludzi młodych: uwarunkowania i konsekwencje. Katowice: Wydawnictwo Uniwersytetu Śląskiego.

Wieczorkowska-Nejtardt, G. (1998). Motivational intelligence: Smart goal setting and action strategies. Warsaw: WISS.

Wieczorkowska, G., \& Burnstein, E. (1999). The role of search costs and screening strategies in social change: Adapting to the transition from socialism to capitalism in Poland. Psychological Science, 10, 98e 105.

Wieczorkowska, G., Krol, G., \& Wierzbinski, J. (2015). Who suffers from a big number of procedures at work? Paper presented at the conference Future Challenges in Management and Business. Istanbul.

Wieczorkowska, G. Burnstein, E. Wierzbiński, J. (2009). When Our Action Style Doesn't Fit the Situation: the Behavioral and Affective Consequences of Using Point or Interval Decision Strategies in Adapting to Environmental Constraints. W: R. Siemieńska P. Radkiewicz (eds.) Społeczeństwo polskie o sobie, gospodarce, polityce w świetle Polskiego Generalnego Sondażu Spolecznego. Warszawa: Wydawnictwo Naukowe Scholar 145-160.

Yukl, G. (2008). How leaders influence organizational effectiveness. The Leadership Quarterly, 19(6), 708-722. 


\section{APPENDIX}

Table i. Questions relating to need for power.

\begin{tabular}{|c|c|c|c|c|c|}
\hline & ar3 & $\operatorname{ar} 13$ & ar16 & ar19 & ar9 \\
\hline & $\begin{array}{l}\text { While working in } \\
\text { a team, Person A } \\
\text { finds it easier when } \\
\text { somebody else } \\
\text { feels responsible } \\
\text { for how things } \\
\text { evolve. Person B } \\
\text { takes complete } \\
\text { responsibility for } \\
\text { their actions. }\end{array}$ & $\begin{array}{l}\text { Person A would } \\
\text { rather delegate } \\
\text { planning and } \\
\text { decision-making } \\
\text { to another team } \\
\text { member. Person B } \\
\text { is keen on planning } \\
\text { and deciding } \\
\text { what other people } \\
\text { should do. }\end{array}$ & $\begin{array}{l}\text { Person A likes } \\
\text { to be replaced } \\
\text { in decision- } \\
\text { making. Person } \\
\mathrm{B} \text { is rather upset } \\
\text { when somebody } \\
\text { else cuts in what } \\
\text { they do. }\end{array}$ & $\begin{array}{l}\text { Person A usually } \\
\text { plays the role of } \\
\text { a leader within } \\
\text { their group. } \\
\text { Person B avoids } \\
\text { responsibility } \\
\text { related with the } \\
\text { role of a group } \\
\text { leader. }\end{array}$ & $\begin{array}{l}\text { While carrying out } \\
\text { tasks in teamwork } \\
\text { projects, Person A } \\
\text { feels good in the } \\
\text { role of a leader. } \\
\text { Person B is } \\
\text { reluctant to decide } \\
\text { on the way the } \\
\text { team's tasks are } \\
\text { performed. }\end{array}$ \\
\hline $\begin{array}{l}\text { Usually } \\
\text { like A }\end{array}$ & 16.7 & 8.3 & 5 & 25.9 & 34.3 \\
\hline $\begin{array}{l}\text { More often } \\
\text { like A }\end{array}$ & 24.3 & 16.6 & 14 & 36.9 & 32.9 \\
\hline $\begin{array}{l}\text { Hard to } \\
\text { say... }\end{array}$ & 5.3 & 8.6 & 9.8 & 8.8 & 6.7 \\
\hline $\begin{array}{l}\text { More often } \\
\text { like B }\end{array}$ & 27.6 & 35 & 39.5 & 18.8 & 18.1 \\
\hline $\begin{array}{l}\text { Usually } \\
\text { like B }\end{array}$ & 26 & 31.6 & 31.7 & 9.7 & 7.9 \\
\hline
\end{tabular}

Note: Cronbach's alpha $=0.79$.

Table ii. Questions relating to need for achievement.

\begin{tabular}{|c|c|c|c|c|c|}
\hline & $\operatorname{ar} 10$ & $\operatorname{ar} 18$ & ar2 & ar8 & $\operatorname{ar} 15$ \\
\hline & $\begin{array}{l}\text { Person A often works } \\
\text { on the verge of what } \\
\text { his or her organism } \\
\text { will handle, or tries to } \\
\text { do more than what is } \\
\text { possible. Person B shies } \\
\text { away from overworking } \\
\text { him or herself, or tries } \\
\text { to do things that she or } \\
\text { he can handle. }\end{array}$ & $\begin{array}{l}\text { When it comes to } \\
\text { herself, person A } \\
\text { is more demanding } \\
\text { than other people, } \\
\text { because she wants } \\
\text { to live as effectively } \\
\text { as possible. Person } \\
\text { B does not want } \\
\text { to bust his or her } \\
\text { hump. }\end{array}$ & $\begin{array}{l}\text { Person A could } \\
\text { probably achieve } \\
\text { more, but he or } \\
\text { she doesn't see } \\
\text { the reason to } \\
\text { work more than } \\
\text { is absolutely } \\
\text { necessary. Person } \\
\text { B works more } \\
\text { than other people. }\end{array}$ & $\begin{array}{l}\text { Person A does not } \\
\text { want to work more } \\
\text { than they pay him } \\
\text { or her. Person B has } \\
\text { a tendency to fully } \\
\text { immerse herself } \\
\text { into the work that } \\
\text { he or she is doing } \\
\text { irrespective of the } \\
\text { pay. }\end{array}$ & $\begin{array}{l}\text { Person A feels } \\
\text { bad if she } \\
\text { feels that there } \\
\text { is little work } \\
\text { for her to do. } \\
\text { Person B likes } \\
\text { tasks that don't } \\
\text { require much } \\
\text { effort from } \\
\text { her part. }\end{array}$ \\
\hline $\begin{array}{l}\text { Usually } \\
\text { like A }\end{array}$ & 27.2 & 40.9 & 12.4 & 25.9 & 38.8 \\
\hline $\begin{array}{l}\text { More often } \\
\text { like A }\end{array}$ & 28.1 & 32.6 & 20.2 & 30.9 & 32.6 \\
\hline $\begin{array}{l}\text { Hard to } \\
\text { say... }\end{array}$ & 8.1 & 6 & 8.1 & 5.9 & 7.9 \\
\hline $\begin{array}{l}\text { More often } \\
\text { like B }\end{array}$ & 24.8 & 14.5 & 32.8 & 21 & 14.1 \\
\hline $\begin{array}{l}\text { Usually } \\
\text { like B }\end{array}$ & 11.7 & 6 & 26.6 & 16.4 & 6.6 \\
\hline
\end{tabular}


Table iii. Questions relating to need for affiliation.

\begin{tabular}{|c|c|c|c|c|c|}
\hline & ar11 & ar20 & $\operatorname{ar} 62$ & $\operatorname{ar} 57$ & $\operatorname{ar} 59$ \\
\hline & $\begin{array}{l}\text { Person A is } \\
\text { regarded an } \\
\text { individualist always } \\
\text { after their own } \\
\text { business. Person } \\
\text { B always tries } \\
\text { to consider other } \\
\text { people's business in } \\
\text { anything they do. }\end{array}$ & $\begin{array}{l}\text { Person A dislikes } \\
\text { to be bothered } \\
\text { by others with } \\
\text { their problems. } \\
\text { Friends of Person } \\
\text { B know they } \\
\text { can always rely } \\
\text { upon them in any } \\
\text { troubled situation. }\end{array}$ & $\begin{array}{l}\text { Person A likes } \\
\text { situations where } \\
\text { there is an } \\
\text { opportunity to } \\
\text { compete with others. } \\
\text { Person B prefers } \\
\text { situations requiring } \\
\text { collaboration rather } \\
\text { than rivalry. }\end{array}$ & $\begin{array}{l}\text { Before making } \\
\text { decision, Person } \\
\text { A attempts to } \\
\text { imagine what } \\
\text { other people feel } \\
\text { or think. Person B } \\
\text { is not interested } \\
\text { in others' point } \\
\text { of view. }\end{array}$ & $\begin{array}{l}\text { Person A doesn't } \\
\text { understand why should } \\
\text { they empathize with } \\
\text { other people's feelings. } \\
\text { Person B considers } \\
\text { several points of view } \\
\text { before deciding how } \\
\text { to behave in any } \\
\text { given situation. }\end{array}$ \\
\hline $\begin{array}{l}\text { Usually } \\
\text { like A }\end{array}$ & 14 & 5 & 15.9 & 37.6 & 4.3 \\
\hline $\begin{array}{l}\text { More often } \\
\text { like A }\end{array}$ & 18.6 & 9.1 & 18.1 & 42.9 & 10.3 \\
\hline $\begin{array}{l}\text { Hard to } \\
\text { say... }\end{array}$ & 7.6 & 3.1 & 5.2 & 4.3 & 6.4 \\
\hline $\begin{array}{l}\text { More often } \\
\text { like B }\end{array}$ & 39.1 & 36.7 & 36.4 & 10.7 & 47.2 \\
\hline $\begin{array}{l}\text { Usually } \\
\text { like B }\end{array}$ & 20.7 & 46 & 24.5 & 4.5 & 31.7 \\
\hline
\end{tabular}

Note: Cronbach's alpha $=0.61$.

Table iv. Questions relating to a methodical working style.

\begin{tabular}{|c|c|c|c|c|c|}
\hline & sr26 & sr17 & $\operatorname{sr} 29$ & sr43 & sr13 \\
\hline & $\begin{array}{l}\text { Person A } \\
\text { commences a task } \\
\text { only once he or } \\
\text { she has thought of } \\
\text { a method to do it, } \\
\text { Person B starts a } \\
\text { task even before } \\
\text { he or she knows } \\
\text { exactly how to do it } \\
\text { and hopes to figure } \\
\text { it out on the fly. }\end{array}$ & $\begin{array}{l}\text { Person A begins } \\
\text { to write an essay } \\
\text { without having } \\
\text { any precise idea } \\
\text { of what will } \\
\text { come up in the } \\
\text { end. Person B } \\
\text { starts with the } \\
\text { clear idea in their } \\
\text { mind and only } \\
\text { then begins to } \\
\text { write. }\end{array}$ & $\begin{array}{l}\text { Person A often } \\
\text { starts tasks } \\
\text { thinking that } \\
\text { things will work } \\
\text { out. Person B } \\
\text { feels worried if he } \\
\text { or she does not } \\
\text { know how to do } \\
\text { something }\end{array}$ & $\begin{array}{l}\text { When person } \mathrm{A} \text { is } \\
\text { preparing to start a } \\
\text { new task he or she } \\
\text { always prepares the } \\
\text { required materials } \\
\text { and tools beforehand, } \\
\text { person B finds the } \\
\text { required tools and } \\
\text { materials while doing } \\
\text { the task as not to stall } \\
\text { with commencing } \\
\text { the task }\end{array}$ & $\begin{array}{l}\text { Person A always } \\
\text { carries out } \\
\text { individual stages } \\
\text { of a task one after } \\
\text { another. Person } \\
\text { B performs them } \\
\text { without any specific } \\
\text { order, depending on } \\
\text { what seems easier } \\
\text { or more interesting } \\
\text { at any given } \\
\text { moment. }\end{array}$ \\
\hline $\begin{array}{l}\text { Usually } \\
\text { like A }\end{array}$ & 14.8 & 18.6 & 14.7 & 22.6 & 15.5 \\
\hline $\begin{array}{l}\text { More often } \\
\text { like A }\end{array}$ & 30.5 & 20.3 & 31 & 37.1 & 20 \\
\hline $\begin{array}{l}\text { Hard to } \\
\text { say... }\end{array}$ & 4.5 & 5.2 & 4.1 & 3.8 & 2.8 \\
\hline $\begin{array}{l}\text { More often } \\
\text { like B }\end{array}$ & 35.3 & 33.8 & 31.7 & 27.8 & 41.6 \\
\hline $\begin{array}{l}\text { Usually } \\
\text { like B }\end{array}$ & 14.8 & 22.1 & 18.4 & 8.8 & 20.2 \\
\hline
\end{tabular}


Table v. Questions relating to reactivity.

\begin{tabular}{|c|c|c|c|c|c|}
\hline & $\operatorname{sr} 10$ & sr49 & $\mathrm{sr} 47$ & $\mathrm{sr} 44$ & sr27 \\
\hline & $\begin{array}{l}\text { Person A does } \\
\text { not like to make } \\
\text { decisions when } \\
\text { feeling pressure. } \\
\text { Person B makes } \\
\text { decisions under } \\
\text { stress easier than } \\
\text { when there is } \\
\text { no pressure. }\end{array}$ & $\begin{array}{l}\text { Person A is } \\
\text { resilient to } \\
\text { stress. Person B } \\
\text { always sleeps } \\
\text { worse before } \\
\text { an important } \\
\text { event (exam, } \\
\text { travelling). }\end{array}$ & $\begin{array}{l}\text { Person A works } \\
\text { very effectively } \\
\text { when time is } \\
\text { running out. } \\
\text { For Person B, } \\
\text { too much time } \\
\text { pressure is } \\
\text { disrupting. }\end{array}$ & $\begin{array}{l}\text { When irritated, Person } \\
\text { A has difficulty in } \\
\text { concentrating upon reading } \\
\text { a book or a paper, for } \\
\text { example reading the same } \\
\text { sentence several times. } \\
\text { Person B knows how } \\
\text { to focus in a stressful } \\
\text { situation if necessary. }\end{array}$ & $\begin{array}{l}\text { For person A, } \\
\text { chaos and too } \\
\text { much incoming } \\
\text { information are } \\
\text { tiring. Person B } \\
\text { is more tired } \\
\text { when here } \\
\text { is too much } \\
\text { monotony. }\end{array}$ \\
\hline $\begin{array}{l}\text { Usually } \\
\text { like A }\end{array}$ & 26.9 & 15.9 & 24.1 & 35.2 & 13.4 \\
\hline $\begin{array}{l}\text { More often } \\
\text { like A }\end{array}$ & 26.2 & 24.5 & 29.8 & 35.9 & 23.3 \\
\hline $\begin{array}{l}\text { Hard to } \\
\text { say... }\end{array}$ & 4.5 & 4.8 & 4.8 & 2.2 & 8.1 \\
\hline $\begin{array}{l}\text { More often } \\
\text { like B }\end{array}$ & 25.7 & 31.2 & 27.1 & 18.4 & 31.9 \\
\hline $\begin{array}{l}\text { Usually } \\
\text { like B }\end{array}$ & 16.7 & 23.6 & 14.1 & 8.3 & 23.3 \\
\hline
\end{tabular}

Note: Cronbach's alpha $=0.58$. 